\title{
Migratory environmental history of the grey mullet Mugil cephalus as revealed by otolith Sr:Ca ratios
}

\author{
C. W. Chang ${ }^{1}$, Y. Iizuka ${ }^{2}$, W. N. Tzeng ${ }^{1,3, *}$ \\ ${ }^{1}$ Institute of Zoology, and ${ }^{3}$ Institute of Fisheries Sciences, College of Life Science, National Taiwan University, Taipei, \\ Taiwan 106, ROC \\ ${ }^{2}$ Institute of Earth Sciences, Academia Sinica, Nankang, Taipei, Taiwan 115, ROC
}

\begin{abstract}
We used an electron probe microanalyzer (EPMA) to determine the migratory environmental history of the catadromous grey mullet Mugil cephalus from the Sr:Ca ratios in otoliths of 10 newly recruited juveniles collected from estuaries and 30 adults collected from estuaries, nearshore (coastal waters and bay) and offshore, in the adjacent waters off Taiwan. Mean $( \pm$ SD) $\mathrm{Sr}$ :Ca ratios at the edges of adult otoliths increased significantly from $6.5 \pm 0.9 \times 10^{-3}$ in estuaries and nearshore waters to $8.9 \pm 1.4 \times 10^{-3}$ in offshore waters $(p<0.01)$, corresponding to increasing ambient salinity from estuaries and nearshore to offshore waters. The mean Sr:Ca ratios decreased significantly from the core $\left(11.2 \pm 1.2 \times 10^{-3}\right)$ to the otolith edge $\left(6.2 \pm 1.4 \times 10^{-3}\right)$ in juvenile otoliths $(\mathrm{p}<$ 0.001). The mullet generally spawned offshore and recruited to the estuary at the juvenile stage; therefore, these data support the use of Sr:Ca ratios in otoliths to reconstruct the past salinity history of the mullet. A life-history scan of the otolith Sr:Ca ratios indicated that the migratory environmental history of the mullet beyond the juvenile stage consists of 2 types. In Type 1 mullet, Sr:Ca ratios range between $4.0 \times 10^{-3}$ and $13.9 \times 10^{-3}$, indicating that they migrated between estuary and offshore waters but rarely entered the freshwater habitat. In Type 2 mullet, the Sr:Ca ratios decreased to a minimum value of $0.4 \times 10^{-3}$, indicating that the mullet migrated to a freshwater habitat. Most mullet beyond the juvenile stage migrated from estuary to offshore waters, but a few mullet less than 2 yr old may have migrated into a freshwater habitat. Most mullet collected nearshore and offshore were of Type 1, while those collected from the estuaries were a mixture of Types 1 and 2 . The mullet spawning stock consisted mainly of Type 1 fish. The growth rates of the mullet were similar for Types 1 and 2 . The migratory patterns of the mullet were more divergent than indicated by previous reports of their catadromous behavior.
\end{abstract}

KEY WORDS: Mugil cephalus $\cdot$ Otolith $\cdot$ Sr:Ca ratio $\cdot$ Migration $\cdot$ Environmental history

\section{INTRODUCTION}

Grey mullet (Mugil cephalus Linnaeus, 1758) are distributed circumglobally between $42^{\circ} \mathrm{N}$ and $42^{\circ} \mathrm{S}$, and are an economically important species for both commercial fisheries and aquaculture because their roes have a high culinary value (Thomson 1966, Nash \& Shehadeh 1980). The adult mullet migrates annually from the coastal waters of mainland China to the offshore waters of SW Taiwan to spawn during the winter (December through January) when 3 to 4 yr old (Tung
1981, Chen \& Su 1986, Huang \& Su 1989). Their eggs and larvae drift with the coastal current to estuaries along the SW to NE coasts of Taiwan where they become juveniles at the age of 1 to 2 mo post-hatching (Tung 1981, Chang \& Tzeng 2000, Chang et al. 2000).

Current knowledge of the migratory history of the mullet has been interpreted fragmentally from the spatio-temporal distribution of the migrating spawners and estuarine-recruited juveniles. The lifetime migratory history, especially between estuarine arrival and spawning migration, is not completely understood. 
Tung (1981) speculated that all the juveniles and adults after spawning might migrate northward to the coastal waters of mainland China to feed until the spawning migration. Liu (1986) postulated that a few juveniles did not migrate northward but resided in the coastal waters around Taiwan. Chen et al. (1989) and Lee (1992) also found immature mullet of various sizes in estuaries and bays of Taiwan. The mullet was also believed to be catadromous, migrating from estuarine brackishwaters to high salinities offshore for breeding (Breder \& Rosen 1966, De Silva 1980, Torricelli et al. 1982). However, the definition of catadromy for the mullet remains controversial because its use of freshwater habitats is not clear (Blaber 1987, McDowall 1988). Thus, the determination of whether the mullet enters freshwater before spawning is critical to clarify the extent of its catadromy.

The fish otolith is composed of calcium carbonate deposited rhythmically as aragonite crystals in a protein matrix (Degens et al. 1969, Pannella 1971). Except for their physiological functions in balance and hearing, fish otoliths also function as a chronological and environmental recorder of the fishes' past life history (Campana \& Neilson 1985, Campana 1999). The ratios of strontium ( $\mathrm{Sr}$ ) to calcium (Ca) in otoliths are positively correlated to ambient salinities (Secor et al. 1995, Tzeng 1996, Kawakami et al. 1998). The temporal

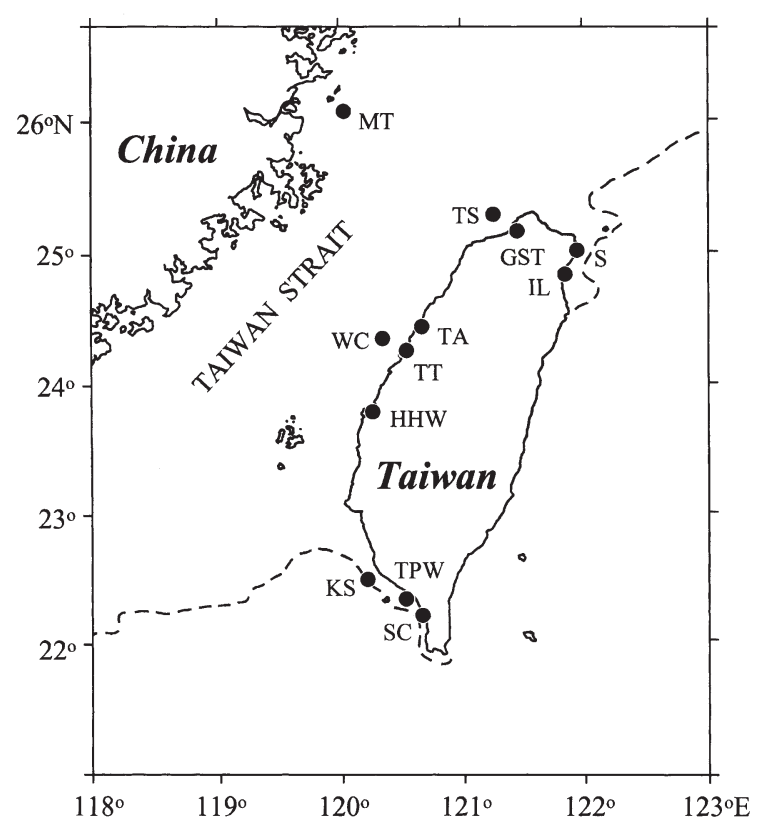

Fig. 1. Mugil cephalus. Sampling sites of grey mullet. Estuary = IL: I-lan River; S: Shuang Creek; GST: Gong-shy-tyan Creek; TA: Ta-an Creek; TT: Ta-tu River; HHW: Hsin-hu-wei Creek; SC: Szu-chung Creek. Nearshore = MT: Ma-tzu; TPW: Ta-peng-wan Bay. Offshore = TS: Tan-shui; WC: Wu-chi; KS: Kan-shan. Dashed line: $200 \mathrm{~m}$ depth contour changes of Sr:Ca ratios in otoliths have been widely applied to determine the migratory environmental histories of diadromous fishes between freshwater and marine environments, including anadromous salmonids (Kalish 1990, Howland et al. 2001, Limburg et al. 2001), striped bass (Secor 1992, Secor \& Piccoli 1996) and catadromous freshwater eels (Tzeng 1994, 1995, 1996, Tzeng \& Tsai 1994, Tzeng et al. 1997, 1999, 2000, 2002a, 2003, Tsukamoto \& Arai 2001, Jessop et al. 2002). Accordingly, the analysis of $\mathrm{Sr}: \mathrm{Ca}$ ratios in otoliths, in combination with age data, makes possible the reconstruction of the migratory environmental history of the mullet and the clarification of its freshwater habitat use.

The aims of the present study were: (1) to validate whether otolith $\mathrm{Sr}$ :Ca ratios could be used to determine retrospectively the migratory environmental history of the mullet, (2) to elucidate its lifetime migratory environmental history, particularly freshwater habitat use, and (3) to reconsider the definition of catadromy as applied to the mullet.

\section{MATERIALS AND METHODS}

Sampling design. We collected 10 newly recruited juvenile mullet from the estuaries of Shuang Creek (S), Ta-an Creek (TA) and Szu-chung Creek (SC) on the northern and western coasts of Taiwan from December 1998 through February 1999 (Fig. 1, Table 1).

In addition, 30 adults were collected from the estuaries, nearshore (coastal waters and bay) and offshore across the dispersal range of the fish (Fig. 1). Of these, 15 were collected from the estuaries of I-lan River (IL), Gong-shy-tyan Creek (GST), Ta-tu River (TT) and Hsin-hu-wei Creek (HHW); 3 were taken from

Table 1. Mugil cephalus. Biological characteristics of juveniles used for otolith Sr:Ca ratio analysis

\begin{tabular}{|lcc|}
\hline $\begin{array}{l}\text { Site, } \\
\text { Sampling date }\end{array}$ & $\begin{array}{c}\text { Fork length } \\
(\mathrm{mm})\end{array}$ & $\begin{array}{c}\text { Weight } \\
(\mathrm{g})\end{array}$ \\
\hline Shuang Creek (S) & & \\
Dec 23, 1998 & 25.32 & 0.13 \\
Jan 24, 1999 & 30.31 & 0.27 \\
Feb 22, 1999 & 32.98 & 0.33 \\
Ta-an Creek (TA) & & \\
Dec 25, 1998 & 31.40 & 0.25 \\
Jan 25, 1999 & 31.87 & 0.25 \\
Feb 25, 1999 & 35.79 & 0.47 \\
Feb 25, 1999 & 33.76 & 0.36 \\
Szu-chung Creek (SC) & & \\
Dec 11, 1998 & 24.83 & 0.14 \\
Jan 17, 1999 & 28.66 & 0.20 \\
Feb 9, 1999 & 24.09 & 0.12 \\
\hline
\end{tabular}


Ta-peng-wan bay (TPW) on the NE and western coasts of Taiwan; 3 were collected from coastal waters influenced by freshwater runoff off Ma-tzu (MT) on the SE coast of mainland China; and 9 were collected during their spawning migration offshore of Tan-shui (TS), Wu-chi (WC) and Kan-shan (KS) on the western coast of Taiwan. Sampling sites and dates, sex, length, weight, gonadosomatic index and age of the mullet are given in Table 2 .

Salinities at the sampling sites were obtained from Su \& Jane (1974), Anonymous (1998), Cheng et al. (1990) and Tzeng et al. (2002b).

Otolith preparation and microprobe analysis. Sagittal otoliths of the mullet were used for the measurement of $\mathrm{Sr}$ and $\mathrm{Ca}$ concentrations. The otoliths were extracted, cleaned, air-dried and embedded in epoxy resin (Epofix, Struers). The lateral view of the mullet otolith is oval in shape in the juvenile stage but becomes oblong in the adult stage. The otolith grows fastest along the antero-posterior axis, moderately along the dorso-ventral axis and slowest along the disto-proximal axis. The otoliths were polished along the sagittal plane for juveniles, but along the frontal plane for adults because the adult otolith curves and elongates dorsally and is concave distally and convex proximally (Fig. 2a). Each otolith was polished using a Metaserv grinder-polisher (Buehler) equipped with various grit sandpapers and $0.05 \mu \mathrm{m}$ alumina slurry and polishing cloth. After polishing, the otoliths were rinsed with deionized water, air-dried and coated with carbon.

The concentrations of $\mathrm{Sr}$ and $\mathrm{Ca}$ in the otoliths were measured with an electron probe microanalyzer, EPMA (JXA-8900R, JEOL) from the primordium to the otolith edge along the posterior maximum growth axis. The beam condition of the EPMA was similar to that used by Tzeng et al. (2002a), but the beam currents, beam sizes, intervals and peak counting times were differed for juveniles ( $3 \mathrm{nA}, 5 \mu \mathrm{m}, 10 \mu \mathrm{m}$ and $120 \mathrm{~s}$ respectively, for $\mathrm{Sr})$ and adults $(5 \mathrm{nA}, 10 \mu \mathrm{m}, 20 \mu \mathrm{m}$ and

Table 2. Mugil cephalus. Biological characteristics of adults used for otolith Sr:Ca ratio analysis. Sampling sites abbreviated as in Fig. 1. FL: fork length; Wt: weight; GSI: gonadosomatic index; -: sex undetermined

\begin{tabular}{|c|c|c|c|c|c|c|c|}
\hline Code & Site & Sampling date & Sex & FL (mm) & Wt (g) & GSI & Age (yr) \\
\hline \multicolumn{8}{|c|}{ Estuary } \\
\hline E1 & IL & May 24, 2000 & - & 207 & 109 & $<0.01$ & $1+$ \\
\hline E2 & IL & May 24, 2000 & - & 292 & 324 & $<0.01$ & $2+$ \\
\hline E3 & IL & Nov 23, 2000 & $0^{17}$ & 297 & 296 & 2.80 & $1+$ \\
\hline E4 & IL & Nov 23, 2000 & ○ & 393 & 549 & 15.16 & $4+$ \\
\hline E5 & GST & Dec 29, 1997 & - & 235 & 168 & $<0.01$ & $1+$ \\
\hline E6 & GST & Jun 23, 1998 & - & 237 & 149 & $<0.01$ & $1+$ \\
\hline E7 & GST & Oct 30,1997 & - & 376 & 730 & 0.22 & $3+$ \\
\hline E8 & GST & Oct 8, 1998 & o & 423 & 940 & 0.34 & $4+$ \\
\hline E9 & $\mathrm{TT}$ & Feb 27, 1998 & $0^{7}$ & 268 & 270 & $<0.01$ & $1+$ \\
\hline E10 & TT & Feb 27, 1998 & $0^{1}$ & 292 & 364 & 0.03 & $2+$ \\
\hline E11 & $\mathrm{TT}$ & Feb 27, 1998 & $0^{1}$ & 333 & 485 & $<0.01$ & $2+$ \\
\hline E12 & $\mathrm{TT}$ & Feb 27, 1998 & 우 & 376 & 626 & 0.28 & $3+$ \\
\hline E13 & HHW & May 15, 2001 & - & 72 & 4 & $<0.01$ & $0+$ \\
\hline E14 & HHW & May 15, 2001 & - & 91 & 8 & $<0.01$ & $0+$ \\
\hline E15 & HHW & May 15, 2001 & - & 269 & 216 & $<0.01$ & $1+$ \\
\hline \multicolumn{8}{|c|}{ Nearshore } \\
\hline N1 & MT & Apr 19, 1998 & 우 19 & 424 & 934 & 0.48 & $3+$ \\
\hline N2 & $\mathrm{MT}$ & Apr 19, 1998 & o & 468 & 1147 & 1.29 & $4+$ \\
\hline N3 & $\mathrm{MT}$ & Apr 19, 1998 & 南 & 471 & 1061 & 0.96 & $5+$ \\
\hline N4 & TPW & Dec 15, 1997 & $0^{7}$ & 260 & 215 & 0.02 & $1+$ \\
\hline N5 & TPW & Dec 15, 1997 & $0^{17}$ & 280 & 308 & 0.02 & $1+$ \\
\hline N6 & TPW & Dec 15, 1997 & $0^{1}$ & 440 & 1120 & 0.03 & $5+$ \\
\hline \multicolumn{8}{|c|}{ Offshore } \\
\hline O1 & TS & Dec 16, 1997 & $0^{1}$ & 421 & 1000 & 0.32 & $4+$ \\
\hline $\mathrm{O} 2$ & TS & Dec 16, 1997 & ㅇ & 422 & 945 & 11.57 & $4+$ \\
\hline $\mathrm{O} 3$ & TS & Dec 16, 1997 & o & 446 & 1200 & 0.93 & $4+$ \\
\hline $\mathrm{O} 4$ & WC & Dec 25, 1997 & o & 453 & 1198 & 11.82 & $4+$ \\
\hline O5 & WC & Dec 25, 1997 & o & 488 & 1321 & 14.09 & $4+$ \\
\hline O6 & WC & Dec 25, 1997 & 웅 & 491 & 1466 & 12.58 & $5+$ \\
\hline $\mathrm{O} 7$ & $\mathrm{KS}$ & Jan 12, 1997 & o & 448 & 1254 & 20.08 & $4+$ \\
\hline O8 & KS & Jan 12, 1997 & $0^{7}$ & 481 & 1309 & 8.70 & $5+$ \\
\hline O9 & KS & Jan 12, 1997 & ㅇ & 500 & 1525 & 2.45 & $5+$ \\
\hline
\end{tabular}



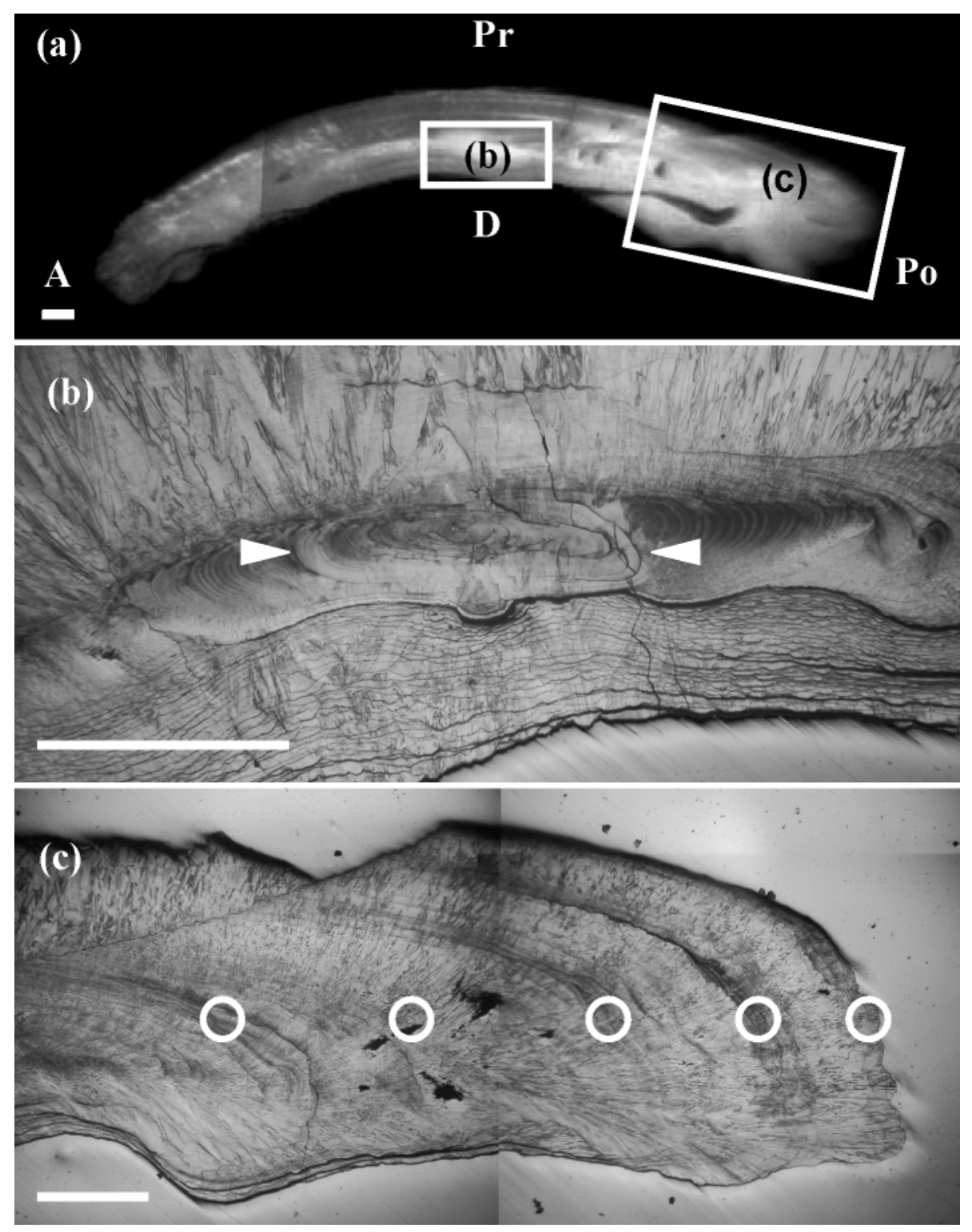

Fig. 2. Mugil cephalus. Frontal section of otolith photographed with reflected light. (a) Whole otolith; (b) estuarine mark (arrowheads) (c) annuli (circled); (b) and (c) magnified from (a). A: anterior; Po: posterior; D: distal; Pr: proximal. Scale bar $=500 \mu \mathrm{m}$

$90 \mathrm{~s}$, respectively, for $\mathrm{Sr})$. Strontianite $\left(\mathrm{SrCO}_{3}\right.$ i National Museum of Natural History [NMNH] R10065) and calcite $\left(\mathrm{CaCO}_{3}\right.$ i NMNH 136321) were used as standards for the calibration of $\mathrm{Sr}$ and $\mathrm{Ca}$ concentrations in otoliths (Jarosewich \& White 1987). The quantitative data were calculated by the ZAF method (Z: atomic number; A: absorption; F: fluorescence correction; Philibert \& Tixier 1968) and Ca was used to normalize the concentration of Sr. The temporal changes in $\mathrm{Sr}: \mathrm{Ca}$ ratios in the otoliths were similar with the same beam condition (e.g. see Mullet Nos. E11, N2, N6 and O6 in Fig. 5) and similar with different beam conditions for the same otolith (e.g. see E15 in Fig. 5 and E13 and 14 in Fig. 6). This indicates that the measurements of $\mathrm{Sr}$ :Ca ratios in the mullet otoliths were stable and repeatable.

After electron probe analysis, the otoliths were repolished to remove the carbon coating and etched with $5 \%$ ethylenediaminetetraacetate (EDTA) to reveal annulus marks for age determination. The otolith $\mathrm{Sr}: \mathrm{Ca}$ ratios were correlated with life history events including estuarine arrival and annulus deposition.

Data analysis. The migratory environmental histories of the adult mullet were classified into 2 types according to age and the temporal changes in the $\mathrm{Sr}$ :Ca ratios in the otoliths. Differences in frequency 
distributions among habitats and among migration patterns for the different mullet environmental history types were examined by a $G$-test (Siegel 1956). Differences in otolith mean radius and $\mathrm{Sr}: \mathrm{Ca}$ ratios among life stages, age groups and salinity habitations were tested by analysis of variance (ANOVA) and a Tukey multiple-comparison test at a significance level of $\alpha=$ 0.05 (Winer 1971).

In addition, the growth curve of the mullet was fitted with the von Bertalanffy growth equation (Ricker 1958). The mean lengths at annulus formation were compared between migratory types by a $t$-test.

\section{RESULTS}

\section{Otolith microstructure}

Estuarine checks and annuli in otoliths from adult mullet were discernible with reflected light after EDTA etching (Fig. $2 \mathrm{~b}, \mathrm{c})$. The mean $( \pm \mathrm{SD})$ radius of the estuarine check in adult mullet otoliths was $435.4 \pm 76.8 \mu \mathrm{m}$ (range 318.6-595.0 $\mu \mathrm{m}$ ). The radius of the estuarine check in adult otoliths was close to the mean $( \pm \mathrm{SD})$ otolith radius of newly recruited juveniles $(387.0 \pm$ $73.9 \mu \mathrm{m}$, range $280.0-510.0 \mu \mathrm{m}$, Table 3 ). Thus, the estuarine check in otoliths of the adult mullet are deposited during their estuarine arrival at the juvenile stage and can be used as a marker to identify the estuarine arrival of the adult.

\section{Otolith Sr:Ca ratios in relation to habitat salinity}

The Sr:Ca transect pattern indicated that $\mathrm{Sr}$ :Ca ratios in the otoliths of juvenile mullet significantly decreased from the core to the otolith edge $(r=-0.73$, $\mathrm{p}<0.001$, Fig. 3). The mean $( \pm \mathrm{SD}) \mathrm{Sr}$ :Ca ratios in the

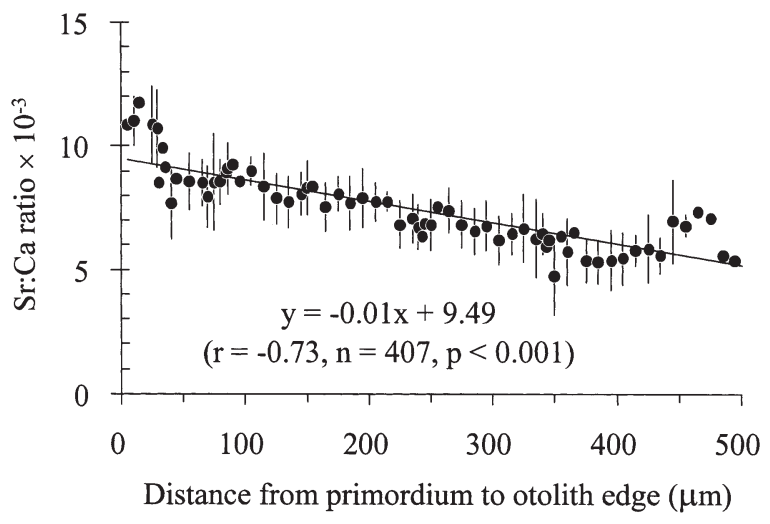

Fig. 3. Mugil cephalus. Changes in mean otolith Sr:Ca ratios from core to otolith edge of 10 juveniles. Vertical lines $= \pm \mathrm{SD}$

core of the otolith $\left(11.2 \times 10^{-3} \pm 1.2 \times 10^{-3}\right)$ were significantly greater than that in otolith edge $\left(6.2 \times 10^{-3} \pm\right.$ $1.4 \times 10^{-3}, \mathrm{p}<0.001$, Table 3). The decrease in $\mathrm{Sr}: \mathrm{Ca}$ ratios from core to edge of the otolith was consistent with larval dispersal from the high-salinity offshore spawning ground to the low-salinity estuarine nursery ground.

The Sr:Ca ratios at the estuarine check of the adult mullet otoliths averaged $5.1 \times 10^{-3} \pm 1.0 \times 10^{-3}$, did not differ significantly among sampling sites, and were similar to those at the juvenile otolith edge $\left(6.2 \times 10^{-3} \pm\right.$ $1.4 \times 10^{-3}$; Table 3). This indicates that the adult mullet probably migrated to a low-salinity estuary at the juvenile stage.

The mean salinity in the sampling sites changed from $23.5 \%$ (range from 1.0 to $34.9 \%$ ) in the estuaries and $23.9 \%(14.3-33.5 \%)$ in the nearshore coastal zone to $34.4 \%$ \% (34.0-34.8\%) in the offshore (Fig. $4 \mathrm{a})$. Maximum salinities were similar among sampling sites, but their mean values increased from estuary and nearshore to offshore. Similarly, the mean $( \pm \mathrm{SD}) \mathrm{Sr}: \mathrm{Ca}$

Table 3. Mugil cephalus. Mean ( $\pm \mathrm{SD}$ ) radius and Sr:Ca ratios at otolith core and edge for juveniles and of estuarine check and annulus $\left(\mathrm{A}_{1-5}\right)$ of otoliths for adults. HG: homogeneous group; same letters indicate that mean values were homogeneous among areas

\begin{tabular}{|c|c|c|c|c|c|c|c|c|c|}
\hline \multirow{2}{*}{$\begin{array}{l}\text { Otolith } \\
\text { area }\end{array}$} & \multirow[t]{2}{*}{$\mathrm{n}$} & \multicolumn{4}{|c|}{ Otolith radius $(\mu \mathrm{m})$} & \multicolumn{4}{|c|}{ Sr:Ca ratio $\times 10^{-3}$} \\
\hline & & Range & Mean \pm SD & $\mathrm{CV}$ & $\mathrm{HG}$ & Range & Mean \pm SD & $\mathrm{CV}$ & $\mathrm{HG}$ \\
\hline \multicolumn{10}{|c|}{ Juveniles } \\
\hline Core & 10 & 11.3-16.3 & $14.5 \pm 1.6$ & 10.7 & $\mathrm{a}$ & $9.4-13.5$ & $11.2 \pm 1.2$ & 10.5 & $\mathrm{~d}$ \\
\hline Edge & 10 & $280.0-510.0$ & $387.0 \pm 73.9$ & 19.1 & $\mathrm{~b}$ & $3.9-8.0$ & $6.2 \pm 1.4$ & 22.9 & $\mathrm{a}$ \\
\hline \multicolumn{10}{|l|}{ Adults } \\
\hline Check & 30 & $318.6-595.0$ & $435.4 \pm 76.8$ & 17.6 & $\mathrm{~b}$ & $2.9-7.0$ & $5.1 \pm 1.0$ & 20.3 & $\mathrm{a}$ \\
\hline $\mathrm{A}_{1}$ & 28 & $2840.0-4030.0$ & $3421.1 \pm 349.5$ & 10.2 & $\mathrm{C}$ & $3.6-10.7$ & $7.9 \pm 1.8$ & 23.2 & $\mathrm{~b}$ \\
\hline $\mathrm{A}_{2}$ & 20 & $3680.0-4760.0$ & $4283.0 \pm 283.6$ & 6.6 & d & $5.3-11.2$ & $8.6 \pm 1.6$ & 18.9 & bc \\
\hline $\mathrm{A}_{3}$ & 17 & $4260.0-5220.0$ & $4927.1 \pm 266.8$ & 5.4 & e & $7.7-13.9$ & $10.0 \pm 1.5$ & 15.2 & $\mathrm{~cd}$ \\
\hline $\mathrm{A}_{4}$ & 14 & $4600.0-5900.0$ & $5383.6 \pm 331.5$ & 6.2 & $\mathrm{f}$ & $5.7-12.4$ & $9.7 \pm 1.7$ & 17.8 & $\mathrm{~cd}$ \\
\hline $\mathrm{A}_{5}$ & 5 & $5600.0-6280.0$ & $5864.0 \pm 259.8$ & 4.4 & g & $8.1-11.7$ & $9.8 \pm 1.4$ & 14.0 & $\mathrm{bcd}$ \\
\hline
\end{tabular}



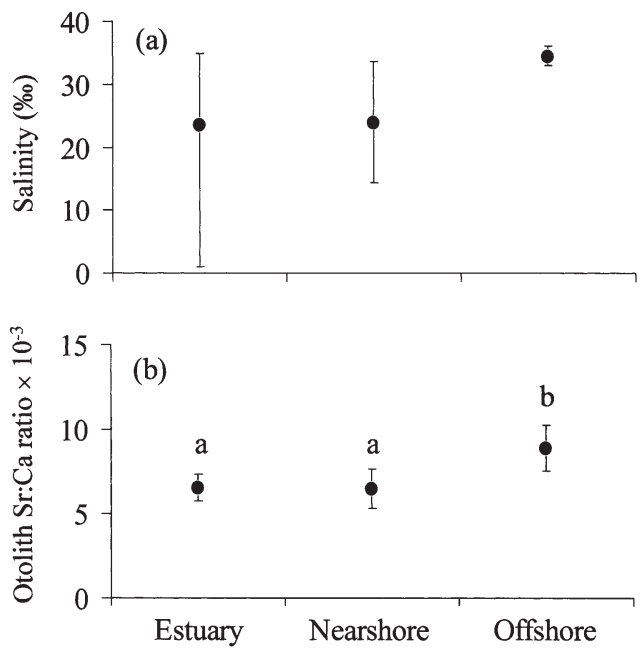

Fig. 4. Mugil cephalus. Mean $( \pm \mathrm{SD})$ salinity and the mean $( \pm \mathrm{SD}) \mathrm{Sr}$ :Ca ratios at otolith edge of adults collected in estuaries (i.e. Sites IL, GST, TT, HHW), nearshore coastal zone (Sites TPW, MT) and offshore (Sites TS, WC, KS) (site abbreviations as in Fig. 1). Same letters above data points indicate that mean $\mathrm{Sr}$ :Ca ratios at otolith edge were homogeneous among designated sites

ratios at the otolith edge of the adult mullet of $\geq 3 \mathrm{yr}$ old significantly increased from $6.5 \times 10^{-3} \pm 0.8 \times 10^{-3}$ (sample size, $\mathrm{n}=4$ ) in the estuaries (Sites IL, GST, TT, HHW) and $6.5 \times 10^{-3} \pm 1.2 \times 10^{-3}(\mathrm{n}=4)$ nearshore (Bay Site TPW and Coastal Site MT) to $8.9 \times 10^{-3} \pm 1.4 \times 10^{-3}$ $(n=9)$ offshore (Sites TS, WC, KS) $(p<0.01$, Fig. 4b). The correspondence between the $\mathrm{Sr}$ :Ca ratios at the edge of adult mullet otoliths and the ambient salinity between estuary and offshore sites indicates that the use of $\mathrm{Sr}$ :Ca ratios in mullet otoliths to reconstruct their migratory salinity history is reliable.

The upper and lower limits of the 95\% confidence interval (CI) of the mean $( \pm \mathrm{SD}) \mathrm{Sr}$ :Ca ratios of $5.1 \times$ $10^{-3} \pm 1.0 \times 10^{-3}$ at the estuarine check of the adult mullet otoliths were $3 \times 10^{-3}$ and $7 \times 10^{-3}$, respectively, and were used as criteria to define the migratory environmental history of the mullet between freshwater and seawater. In other words, the fish was expected to have migrated to the high-salinity offshore sites if the otolith $\mathrm{Sr}$ :Ca ratios were greater than the upper limit of the $\mathrm{CI}$, to have migrated to freshwater sites if the ratios were less than the lower limit of the CI, and to have migrated to brackish estuaries if the ratios fluctuated between the upper and lower limits of the CI.

\section{Temporal changes in Sr:Ca ratios in adult otoliths}

The migratory environmental history of the mullet was divided into 2 types based on temporal changes in otolith $\mathrm{Sr}$ :Ca ratios:
Type 1. Most $\mathrm{Sr}$ :Ca ratios beyond the estuarine check in the otoliths of Type 1 mullet adults fluctuated between $4 \times 10^{-3}$ and $13.9 \times 10^{-3}$ and were seldom less than $3 \times 10^{-3}$ (Fig. 5), indicating that after the juvenile stage the mullet had migrated between estuary and offshore waters and had rarely entered freshwaters. The ages of Type 1 mullet ranged from 1 to $5 \mathrm{yr}$ old, but most were aged 4 to $5 \mathrm{yr}$ (Fig. 5, Table 2).

Type 2. Sr:Ca ratios beyond the estuarine check in the otoliths of Type 2 adult mullet fluctuated between $0.4 \times 10^{-3}$ and $12.5 \times 10^{-3}$ (Fig. 6), indicating that they had migrated between freshwater and offshore waters. The recruitment time of the mullet to freshwater differed among individuals, lasting from 1 to $2 \mathrm{yr}$. In some cases, the mullet all directly entered freshwater after estuarine arrival (e.g. Mullet Nos. E2, 5, 13, 14, and N1 and $\mathrm{O} 4$ in Fig. 6). Among these, Mullet E2 and O4 remained in freshwater for approximately $1 \mathrm{yr}$ and then migrated to higher-salinity waters, whereas Mullet N1 remained in freshwater for a short time only (ca. 1-2 mo) and then migrated to higher salinities. Mullet E5 migrated between freshwater and brackishwater in the first year. Mullet E13 and E14 remained in freshwater after estuarine arrival until they were captured. In other cases, the mullet delayed entering freshwater after estuarine arrival (e.g. Mullet Nos. E1, 6, 9, 10 in Fig. 6). Among these, Mullet E1 and E10 resided in brackish or highly saline waters for approximately 6 mo and then migrated between freshwater and brackishwaters. Mullet E6 and E9 had migrated between brackish and high-salinity waters for $1 \mathrm{yr}$ and then entered freshwater. Thus, the Type 2 mullet migrates to freshwater after the juvenile stage, but the duration of freshwater residence differs among individuals.

\section{Composition of migratory patterns}

The composition of Types 1 and 2 mullet differed significantly among habitats $(\mathrm{p}<0.001$, Table 4$)$. The pro-

Table 4. Mugil cephalus. Percent composition of Types 1 and 2 as a function of migratory status and sampling sites. Site abbreviations as in Fig. 1

\begin{tabular}{|lrcc|}
\hline \multirow{2}{*}{$\begin{array}{l}\text { Season, } \\
\text { Sites }\end{array}$} & $\mathrm{n}$ & \multicolumn{2}{c|}{ Composition (\%) } \\
& & Type 1 & Type 2 \\
\hline Non-spawning season & & & \\
$\quad$ Estuary (IL, GST, TT, HHW) & 15 & 46.7 & 53.3 \\
$\quad$ Nearshore (MT, TPW) & 6 & 83.3 & 16.7 \\
Spawning season & & & \\
$\quad$ Offshore (TS, WC, KS) & 9 & 88.9 & 11.1 \\
Total & 30 & 66.7 & 33.3 \\
\hline
\end{tabular}



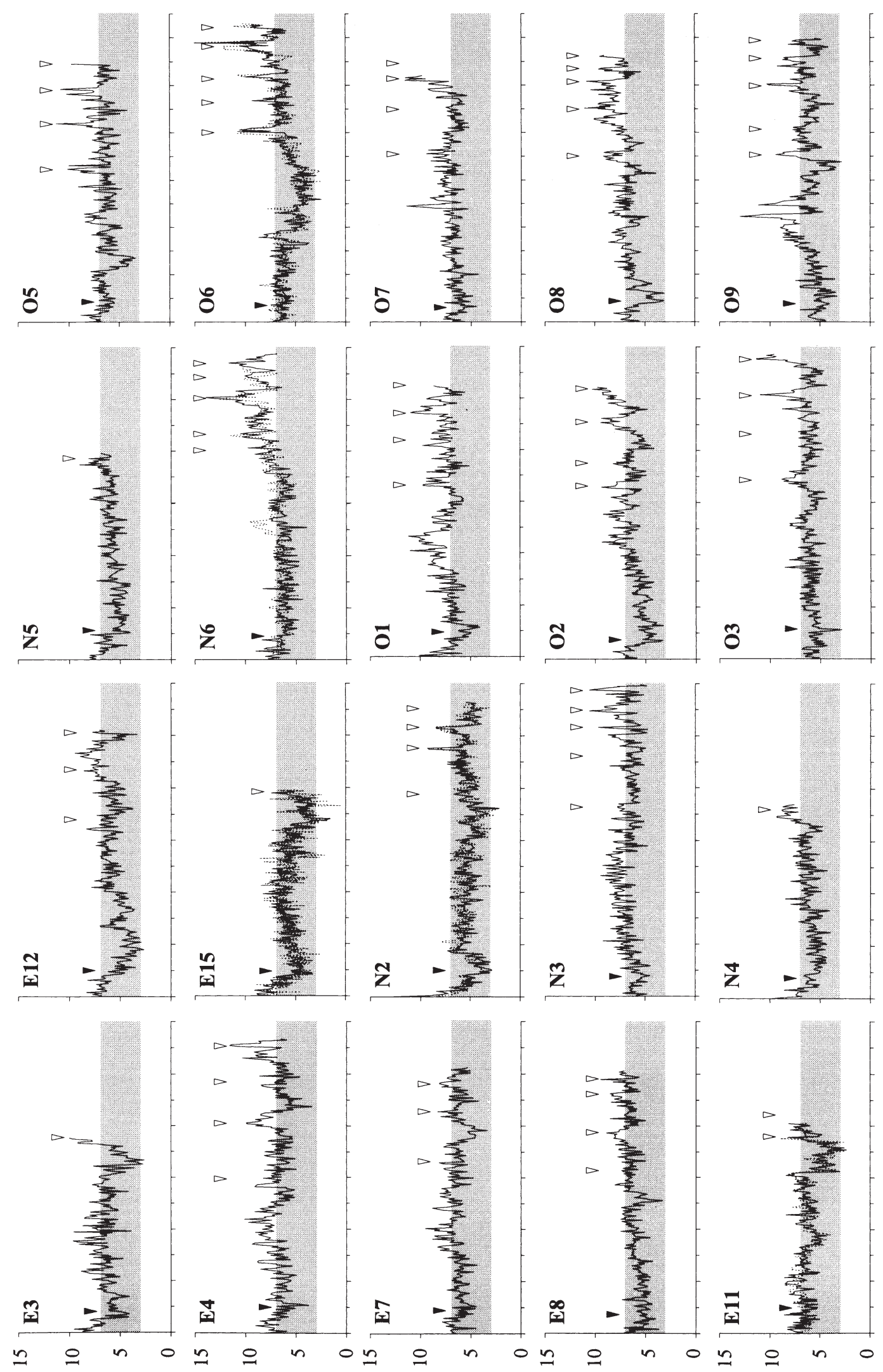

$\circ$

8

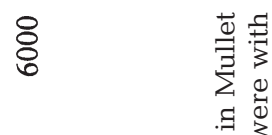

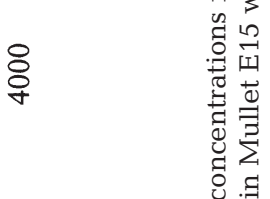

ठํำ

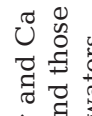

के वै

当: 䓈

든 윰

$8 \quad$ चु चू

焉

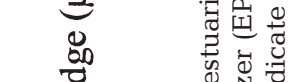

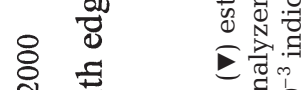

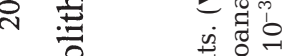

낭

-

\&

言专热

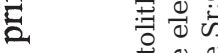

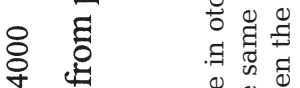

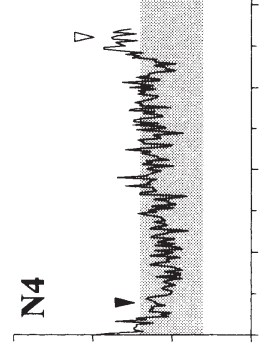

\&.

禺过

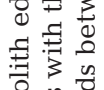

응 원

용

范苞

- 音

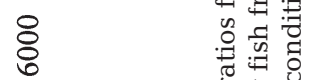

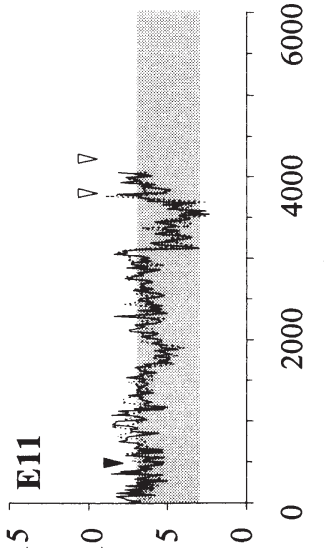

范苟

is

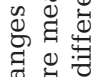

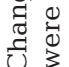

ปี

कृ

สูร

in

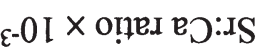

象 
portion of Type 1 mullet was significantly higher in the nearshore $(83.3 \%)$ and offshore $(88.9 \%)$ sites irrespective of season (spawning or non-spawning), but the proportion of Type 2 mullet was slightly higher in the estuaries $(53.3 \%)$ during non-spawning season. In other words, the proportion of mullet entering freshwaters (Type 2) was lower for the nearshore and offshore populations than the estuarine population.

Conversely, the proportion of Type 1 mullet (88.9\%) was higher than Type 2 during the spawning season $(11.1 \%$, Table 4$)$ suggesting that the spawning stock of the mullet was mostly composed of Type 1 fish that did not enter freshwater.
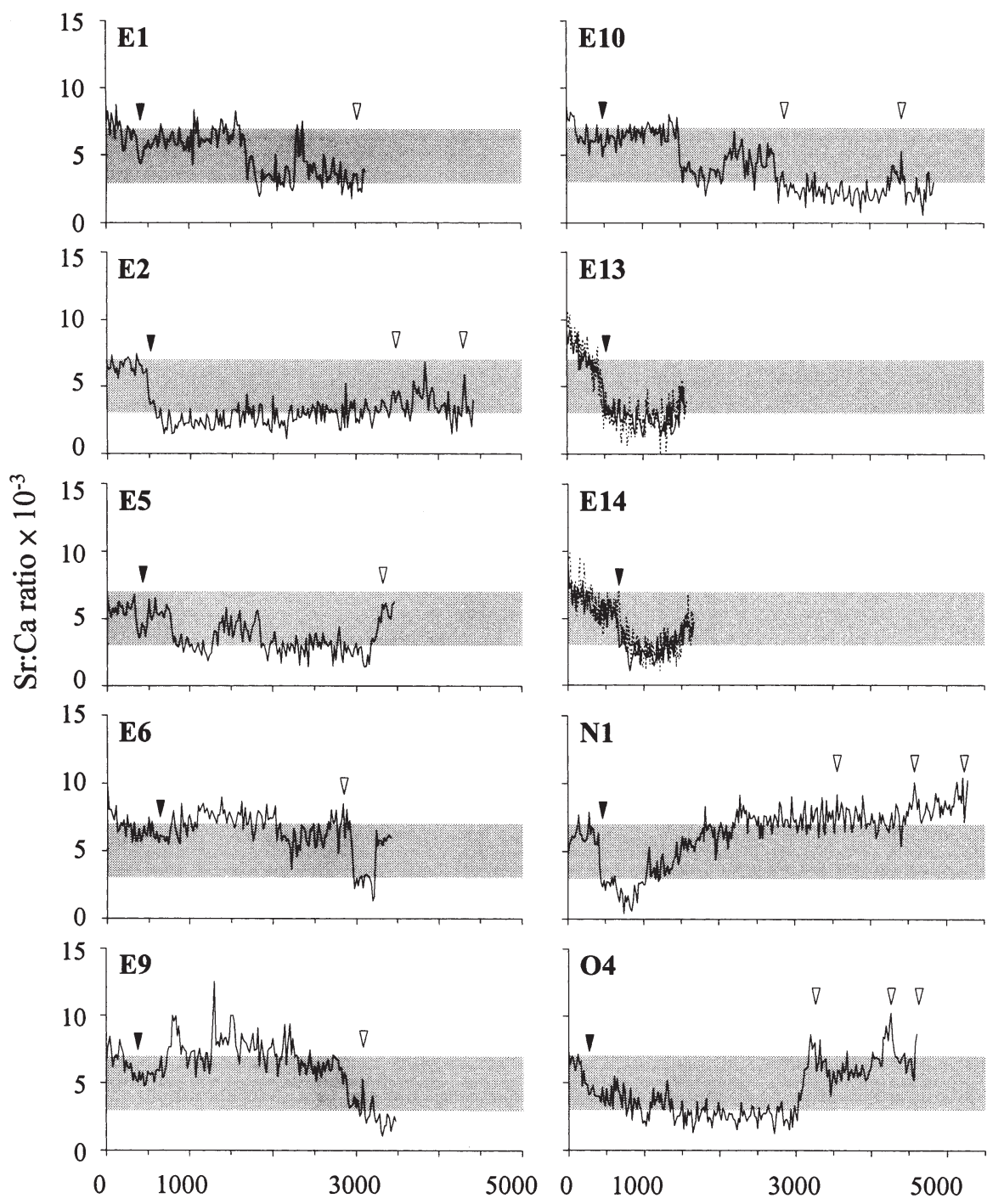

Distance from primordium to otolith edge $(\mu \mathrm{m})$

Fig. 6. Mugil cephalus. Changes in Sr:Ca ratios from core to otolith edge in the otoliths of Type 2 adults. $(\boldsymbol{\nabla})$ estuarine check; $(\nabla)$ annuli. Sr and Ca concentrations in Mullet Nos. E13 and E14 were measured for fish from 2 transects with different electron probe microanalyzer (EPMA) beam conditions. Grey bands between the Sr:Ca ratios 3 to $7 \times 10^{-3}$ indicate migration in brackishwaters

\section{Age-related habitat use}

The habitat use of the mullet changed with age (Fig. 7). At Age $1 \mathrm{yr}$, about $26.7 \%$ of mullet inhabited $13.3 \%$ in the first year to $41.7 \%$ in the fifth year. Thus a small portion of mullet inhabited freshwater and the number of mullet migrating offshore from freshwaters estuary increased with age.

Beyond the estuarine check in adult otoliths, the peak Sr:Ca ratios corresponded to annuli (Figs. 5 \& 6). Mean $( \pm \mathrm{SD}) \mathrm{Sr}$ :Ca ratios at the annuli ranged from $7.9 \pm 1.8 \times 10^{-3}$ to $10.0 \pm$ $1.5 \times 10^{-3}$ and were significantly greater than at the estuarine check in otoliths of both adult $\left(5.1 \pm 1.0 \times 10^{-3}\right)$ and juvenile mullet $\left(6.2 \pm 1.4 \times 10^{-3}\right.$, Table 3). The frequency distribution of peak $\mathrm{Sr}$ :Ca ratios could be roughly divided into 2 groups, one comprising the first and second annuli and the other the third to fifth annuli. The mean peak $\mathrm{Sr}$ :Ca ratios were larger in the latter than in the former group (Fig. 8). The mullet presumably tended to migrate to higher-salinity offshore waters after their third year.

\section{Growth}

The maximum otolith radius and fork length of the mullet were linearly correlated (Fig. 9), indicating that otolith growth reflects the somatic growth of the fish. The mean radius of the estuarine check and the successive annuli in otoliths of the adult differed significantly (Table 3). Annual increments within the otoliths were largest (ca. $3500 \mu \mathrm{m}$ ) within the first year and decreased dramatically to ca. $850 \mu \mathrm{m}$ within the second year and ca. $650 \mu \mathrm{m}$ to $<500 \mu \mathrm{m}$ within the third to fifth years, indicating that mullet growth was fastest in the first year and declined with age. The coefficient of variation (CV) values of the otolith radius at both the estuarine check and first annulus were larger than for succeeding annuli for adults, indicating greater variability of growth rate in the early life stage. 
The mean lengths of the mullet at annulus formation were not significantly different between migratory history types (Fig. 10). This indicated that migratory environments did not affect growth rates of the mullet. The age-length data of different migratory types were combined and a theoretical growth curve was fitted with the von Bertalanffy growth equation as follows:

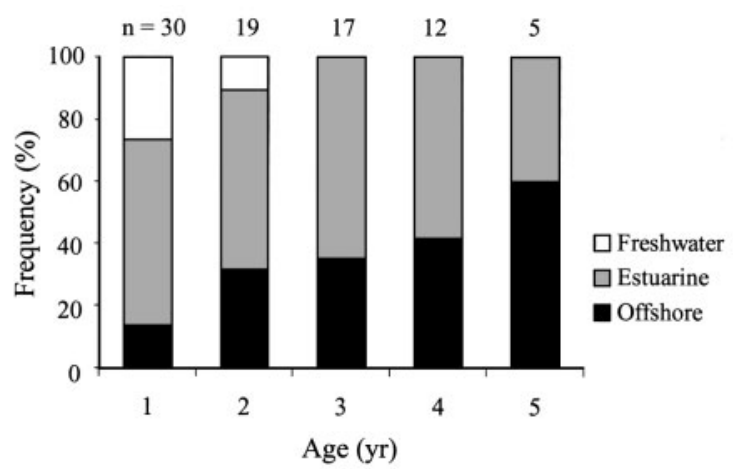

Fig. 7. Mugil cephalus. Frequency distribution of age-related habitat use. $\mathrm{n}=$ sample size

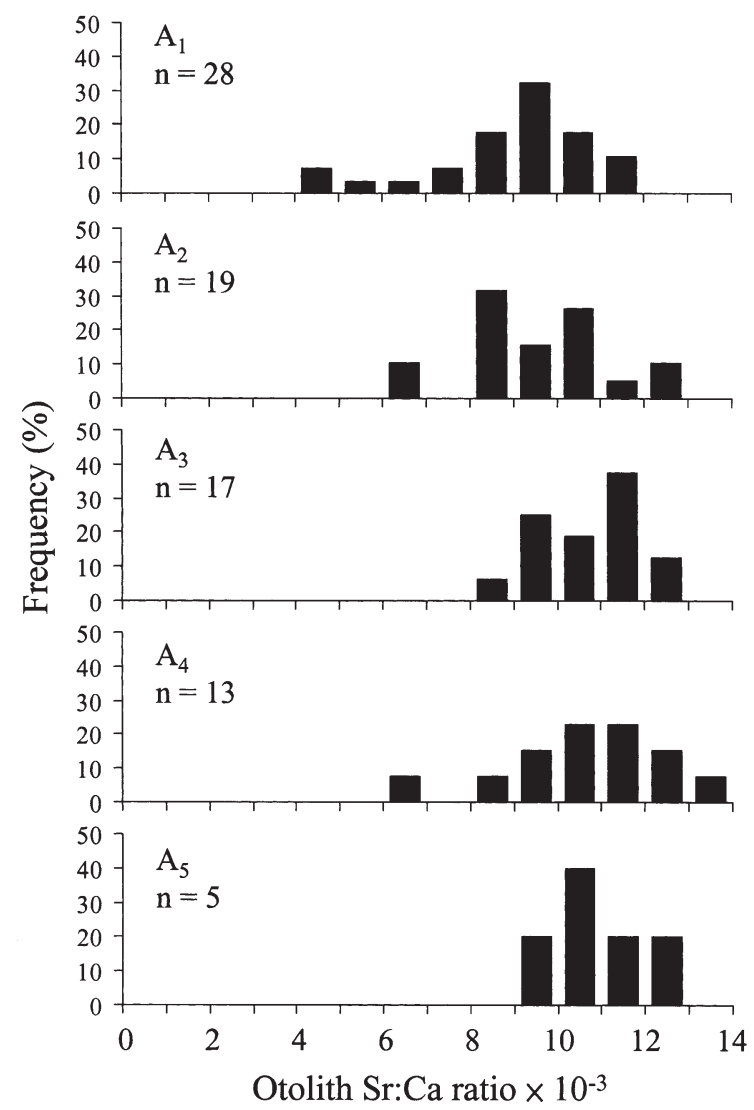

Fig. 8. Mugil cephalus. Frequency distribution of Sr:Ca ratios at annulus $\left(\mathrm{A}_{1-5}\right)$ in otoliths. $\mathrm{n}=$ sample size

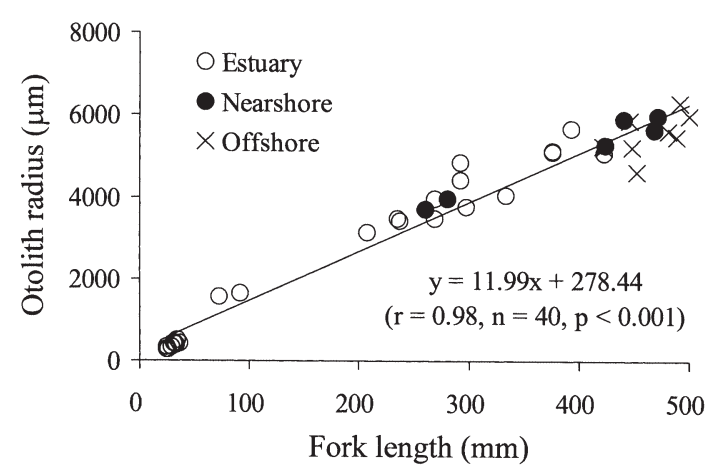

Fig. 9. Mugil cephalus. Relationship between fork length and otolith radius

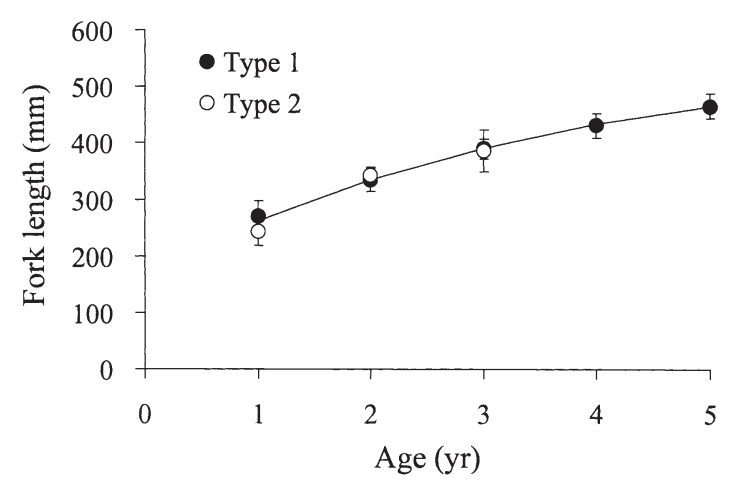

Fig. 10. Mugil cephalus. Relationship between fork length and age. Vertical lines $= \pm \mathrm{SD}$

$$
L_{t}=571.3\left(1-e^{(-0.27[t+1.29])}\right)
$$

where $L_{t}$ was the theoretical length at age $t$, the maximum estimated length was $571.3 \mathrm{~mm}$ and the growth coefficient was $0.27 \mathrm{yr}^{-1}$.

\section{DISCUSSION}

\section{Sr:Ca otolith ratios as indicator of environmental salinity}

The Sr:Ca ratios in otoliths of both juvenile and adult mullet were positively correlated with the salinities of the sampling sites (Fig. 4). Thus, the Sr:Ca ratios in otoliths can be used to reconstruct the migratory environmental history of the mullet, as for other fishes (Tzeng \& Tsai 1994, Secor et al. 1995, Secor \& Rooker 2000, Limburg et al. 2001).

Based on our findings, the $\mathrm{Sr}$ :Ca ratios in otoliths of the mullet decreased to less than $3 \times 10^{-3}$ when the fish migrated to freshwater, fluctuated between 3 and $7 \times$ $10^{-3}$ in estuarine brackishwaters, and were greater 
than $7 \times 10^{-3}$ in high-salinity offshore waters. Secor \& Rooker (2000) found a similar relationship between otolith Sr:Ca ratios and environmental salinity. They divided estuarine fishes into freshwater (salinity range of 0 to $5 \%$; mean $\mathrm{Sr}$ :Ca ratios of $1.97 \times 10^{-3}$ ), estuarine ( 5 to $25 \%$; $5.03 \times 10^{-3}$ ) and marine $\left(>25 \%\right.$; $7.43 \times 10^{-3}$ ) habitats. Tsukamoto \& Arai (2001) divided the Japanese eel Anguilla japonica into river, estuarine and sea eels when otolith $\mathrm{Sr}$ :Ca ratios were $<2.5 \times 10^{-3}$, between 2.5 and $6 \times 10^{-3}$ and $>6 \times 10^{-3}$, respectively. Jessop et al. (2002) divided the American eel A. rostrata into freshwater and estuarine residents when otolith Sr:Ca ratios were $<4 \times 10^{-3}$ and $>5 \times 10^{-3}$, respectively. Tzeng et al. (2003) used the $\mathrm{Sr}$ :Ca ratio of $4 \times 10^{-3}$ in otoliths of the Japanese eel as a criterion to distinguish freshwater and seawater contingents of the eel. Otolith Sr:Ca ratios relative to ambient salinity seem similar among different species suggesting that their use to reconstruct the past salinity history of a fish is reliable.

\section{Sr:Ca otolith ratios and their implication in migratory history of the mullet}

The migratory environmental histories of juvenile mullet collected in the estuaries and those of the adult mullet collected in the estuaries, nearshore and offshore, were reconstructed from the temporal changes of the $\mathrm{Sr}$ :Ca ratios in their otoliths. The Sr:Ca ratios in juvenile otoliths decreased from the core to the otolith edge (Fig. 3), indicating that the mullet larvae dispersed away from the high-salinity offshore spawning ground and grew to juveniles in the estuaries, as expected (Tung 1981, Chang et al. 2000). The Sr:Ca ratios beyond the estuarine check in the otoliths of Type 2 mullet (e.g. Mullet Nos. E2, 5, 13, 14, N1 and O4 in Fig. 6) indicated that the fish resided in freshwater in Taiwan during the first year. The Sr:Ca ratios at the edge of adult mullet otoliths collected in Taiwanese estuaries were lower (e.g. E1, 6, 9, 10 in Fig. 6), indicating that the mullet resided in freshwater after $1 \mathrm{yr}$. The temporal change in $\mathrm{Sr}$ :Ca ratios in otoliths of Type 2 mullet supports the hypothesis that some mullet did not migrate to the coastal waters of mainland China but resided in the coastal waters of Taiwan (Liu 1986).

The mullet migrated to the spawning ground at approximately 3 to $5 \mathrm{yr}$ of age (Table 2). The $\mathrm{Sr}: \mathrm{Ca}$ ratios in otoliths of mullet older than $3 \mathrm{yr}$ were found to have oscillated annually, with a peak $\mathrm{Sr}$ :Ca ratio at the annulus check (Figs. $5 \& 6$ ). The annuli in otoliths of adult mullet are formed in the winter during spawning (Ibáñez-Aguirre \& Gallardo-Cabello 1996). Thus, the peak Sr:Ca ratio and annulus in adult mullet otoliths were deposited simultaneously in the winter, as in the
European eel (Tzeng et al. 1999). In other words, the fluctuations in the $\mathrm{Sr}$ :Ca ratios in adult mullet otoliths corresponded to their migration between feeding grounds in the low-salinity coastal waters of mainland China and the high-salinity offshore spawning ground off the SW coast of Taiwan, which is influenced by the Kuroshio Current in winter (Tung 1981, Huang \& Su 1989). Also, a few adult mullet also showed a peak Sr:Ca ratio 1 and/or 2 yr of age (e.g. Mullet Nos. O5, 6, 8 in Fig. 5 and O4 in Fig. 6). Some immature mullet might migrate with the spawners to the spawning ground, as reported by Hwang (1986) and Huang \& Su (1989).

On the other hand, the feeding activity of mullet may decrease and their growth rates become lower in the winter. The deposition rate of $\mathrm{Sr}$ in the otolith may be negatively correlated to both water temperature (Radtke 1989, Townsend et al. 1992, Tzeng 1994) and growth rate of the fish (Sadovy \& Severin 1992). Therefore, the temperature and fish growth rate may interact with salinity to regulate the $\mathrm{Sr}: \mathrm{Ca}$ ratios in mullet otoliths. Interactive effects of temperature and salinity on otoliths were also found for black bream Acanthopagrus butcheri (Elsdon \& Gillanders 2002).

\section{Divergent migratory behaviour of the mullet}

The mullet was shown to comprise 2 coexisting migratory types in coastal waters of Taiwan (Table 4). Consequently, we do not completely agree with the hypothesis that the mullet is a catadromous fish spending most of its life in freshwater before migrating offshore for spawning (De Silva 1980, Torricelli et al. 1982).

Type 1 mullet is not a typical catadromous fish, because it does not migrate to freshwater but moves between estuarine and offshore waters (Fig. 5). One of the Type 2 mullet may have been catadromous, as are mullet in Australia (Thomson 1966) and the USA (Shireman 1975), which reside in freshwater before maturation at 3 to $4 \mathrm{yr}$ of age (e.g. Mullet No. E10 in Fig. 6). Conversely, 2 of the Type 2 mullet emigrated from the freshwater habitat before $1 \mathrm{yr}$ of age and did not remain in freshwater until maturation (i.e. N1 and O4 in Fig. 6) as do mullet in freshwaters of South Africa (Bok 1979) and western Australia (Chubb et al. 1981). Strictly, these 2 mullet could be only categorized as marine amphidromous because they emigrated before maturation (McDowall 1988). The remaining 7 mullet of the Type 2 mullet also could not be categorized as catadromous or amphidromous because they resided in freshwater only at an early stage ( $\leq 1 \mathrm{yr}$ old). Thus, the migratory pattern of mullet is more plastic and complicated than previously thought. The term 
'catadromy' is insufficient to represent the diverse migratory patterns of mullet, which seem to be more a diadromous continuum (McDowall 1988) in a sequential succession of 4 ecophenotypes, namely marine, euryhaline, amphidromous and catadromous, as in the directional evolution of diadromous fishes as proposed by Gross (1987).

Mullet can inhabit freshwater, estuarine and offshore waters, but tend to inhabit high-salinity offshore waters after maturation (Figs. $7 \&$ 8). This phenomenon was also found in the Mediterranean grey mullet, in which the mature mullet prefer polyhaline areas and strongly avoid freshwater sites (Cardona 2000). Young mullet may have greater phenotypic plasticity and more divergent migratory patterns than older mullet. The migratory patterns of mullet collected from estuaries were more divergent than those from nearshore and offshore coastal areas (Table 4). The salinity was more varied and productivity was higher in the estuary than offshore (Haedrich \& Hall 1976). The mullet is a euryhaline fish and can tolerate a wide range of salinity. Consequently, the divergent migratory behaviour of the mullet might be simply an expression of its euryhaline nature and/or an attempt to seek the maximum evolutionary fitness for foraging (Gross 1987).

Acknowledgements. The study was financially supported by the National Science Council, Republic of China (Grant numbers NSC-89-2611-M002-039, NSC-90-2611-M002-019 and NSC-91-2611-M002-023). The authors are grateful to Mr. C. S. Huang of the Department of Fisheries Sciences, National Taiwan Ocean University, Dr. S. C. Lee of the Institute of Zoology, Academia Sinica, Mr. C. C. Liu and Dr. Y. S. Lin of the Institute of Zoology, National Taiwan University, Mr. C. C. Han of the National Museum of Marine Biology and Aquarium for providing specimens; to Mr. C. S. Chen for the fieldwork; to Mr. B. M. Jessop of the Department of Fisheries and Oceans, Bedford Institute of Oceanography, Canada, and the anonymous referees for helpful comments on an earlier draft of the manuscript.

\section{LITERATURE CITED}

Anonymous (1988) A comprehensive oceanographic survey of the central and northern part of the Taiwan Strait. Science Publication, Beijing

Blaber SJM (1987) Factors affecting recruitment and survival of mugilids in estuaries and coastal waters of southeastern Africa. Am Fish Soc Symp 1:507-518

Bok AH (1979) The distribution and ecology of two mullet species in some fresh water rivers in the Eastern Cape, South Africa. J Limnol Soc South Africa 5:97-102

Breder CM, Rosen DE (1966) Modes of reproduction in fishes. TFH Publishers, Nepture City, NJ

Campana SE (1999) Chemistry and composition of fish otoliths: pathways, mechanisms and applications. Mar Ecol Prog Ser 188:263-297

Campana SE, Neilson JD (1985) Microstructure of fish otoliths. Can J Fish Aquat Sci 42:1014-1032
Cardona L (2000) Effects of salinity on the habitat selection and growth performance of Mediterranean flathead grey mullet Mugil cephalus (Osteichthyes, Mugilidae). Estuar Coast Shelf Sci 50:727-737

Chang CW, Tzeng WN (2000) Species composition and seasonal occurrence of mullet (Pisces, Mugilidae) in the Tanshui estuary, northwest Taiwan. J Fish Soc Taiwan 27: 253-262

Chang CW, Tzeng WN, Lee YC (2000) Recruitment and hatching dates of grey mullet (Mugil cephalus L.) juveniles in the Tanshui estuary of northwest Taiwan. Zool Stud 39:99-106

Chen WY, Su WC (1986) Reproductive biology of the grey mullet, Mugil cephalus L. of Taiwan. In: Su WC (ed) Study on the resource of grey mullet in Taiwan, 1983-1985. Kaohsiung Branch TFRI, Kaohsiung, p 73-80

Chen WY, Su WC, Shao KT, Lin CP (1989) Morphometric studies of the grey mullet (Mugil cephalus) from the waters around Taiwan. J Fish Soc Taiwan 16(3):153-163

Cheng HH, Hsieh CS, Su MS (1990) Ecological and environmental survey of the Tapen Bay. II. Distribution of plankton. TungKang Branch TFRI, TungKang

Chubb CF, Potter IC, Grant CJ, Lenanton RCJ, Wallace J (1981) Age structure, growth rates and movements of sea mullet, Mugil cephalus L., and yellow-eyed mullet, Aldrichetta forsteri (Valenciennes), in the Swan-Avon River system, Western Australia. Aus J Mar Freshw Res 32: 605-628

Degens ET, Deuser WG, Haedrich RL (1969) Molecular structure and composition of fish otoliths. Mar Biol 2:105-113

De Silva SS (1980) Biology of juvenile grey mullet: a short review. Aquaculture 19:21-36

Elsdon TS, Gillanders BM (2002) Interactive effects of temperature and salinity on otolith chemistry: challenges for determining environmental histories of fish. Can J Fish Aquat Sci 59:1796-1808

Gross M (1987) The evolution of diadromy in fishes. Am Fish Soc Symp 1:14-25

Haedrich RL, Hall CAS (1976) Fishes and estuaries. Oceanus 19:55-63

Howland KL, Tonn WM, Babaluk JA, Tallman RF (2001) Identification of freshwater and anadromous inconnu in the Mackenzie River system by analysis of otolith strontium. Trans Am Fish Soc 130:725-741

Huang CS, Su WC (1989) Studies on the fluctuations of fishing conditions for grey mullet (Mugil cephalus Linnaeus) from the western coast of Taiwan. J Fish Soc Taiwan 16: $47-83$

Hwang SY (1986) Age composition, size distribution and length-weight relationship of grey mullet (Mugil cephalus) in 1984. In: Su WC (ed) Study on the resource of grey mullet in Taiwan, 1983-1985. Kaohsiung Branch TFRI, Kaohsiung, p 57-62

Ibáñez-Aguirre AL, Gallardo-Cabello M (1996) Age determination of the grey mullet Mugil cephalus L. and the white mullet Mugil curema V. (Pisces: Mugilidae) in Tamiahua lagoon, Veracruz. Cienc Mar 22:329-345

Jarosewich E, White JS (1987) Strontianite reference sample for electron microprobe and SEM analyses. J Sediment Petrol 57:762-763

Jessop BM, Shiao JC, lizuka Y, Tzeng WN (2002) Migratory behaviour and habitat use by American eels Anguilla rostrata as revealed by otolith microchemistry. Mar Ecol Prog Ser 233:217-229

Kalish JM (1990) Use of otolith microchemistry to distinguish the progeny of sympatric anadromous and non-anadromous salmonids. Fish Bull US 88:657-666 
Kawakami Y, Mochioka N, Morishita K, Tajima T, Nakagawa H, Toh H, Nakazono A (1998) Factors influencing otolith strontium/calcium ratios in Anguilla japonica elvers. Environ Biol Fish 52:299-303

Lee SC (1992) Fish fauna and abundance of some dominant species in the estuary of Tanshui, northwestern Taiwan. J Fish Soc Taiwan 19:263-271

Limburg KE, Landergren P, Westin L, Elfman M, Kristiansson $P$ (2001) Flexible modes of anadromy in Baltic sea trout: making the most of marginal spawning streams. J Fish Biol 59:682-695

Liu CH (1986) Survey of the spawning grounds of grey mullet. In: Su WC (ed) Study on the resource of grey mullet in Taiwan, 1983-1985. Kaohsiung Branch TFRI, Kaohsiung, p 63-72

McDowall RM (1988) Diadromy in fishes: migrations between freshwater and marine environments. Cambridge University Press, Cambridge

Nash EC, Shehadeh ZH (1980) Review of breeding and propagation techniques for grey mullet, Mugil cephalus L. ICLARM Stud Rev 3:1-40

Pannella G (1971) Fish otolith: daily growth layers and periodical patterns. Science 173:1124-1127

Philibert J, Tixier R (1968) Electron penetration and the atomic number correction in electron probe microanalysis. Br J Appl Phys 2:685-694

Radtke RL (1989) Strontium-calcium concentration ratios in fish otoliths as environmental indicators. Comp Biochem Physiol A 92:189-193

Ricker WE (1958) Handbook of computations for biological statistics of fish populations. Bull Fish Res Board Can 119: $1-300$

Sadovy Y, Severin KP (1992) Trace elements in biogenic aragonite: correlation of body growth and strontium levels in the otoliths of the white grunt, Haemulon plumieri (Pisces. Haemulidae). Bull Mar Sci 50:237-257

Secor DH (1992) Application of otolith microchemistry analysis to investigate anadromy in Chesapeake Bay striped bass Morone saxatilis. Fish Bull US 90:798-806

Secor DH, Piccoli PM (1996) Age- and sex-dependent migrations of striped bass in the Hudson River as determined by chemical microanalysis of otoliths. Estuaries 19: 778-793

Secor DH, Rooker JR (2000) Is otolith strontium a useful scalar of life cycles in estuarine fishes? Fish Res 46:359-371

Secor DH, Henderson-Arzapalo A, Piccoli PM (1995) Can otolith microchemistry chart patterns of migration and habitat utilization in anadromous fishes? J Exp Mar Biol Ecol 192:15-33

Shireman JV (1975) Gonadal development of striped mullet (Mugil cephalus) in fresh water. Prog Fish-Cult 37:205-205

Siegel S (1956) Nonparametric statistics for the behavioral sciences. McGraw-Hill, New York

$\mathrm{Su}$ WC, Jane KF (1974) Oceanographic investigation in the

Editorial responsibility: Otto Kinne (Editor),

Oldendorf/Luhe, Germany
Taiwan Strait during the grey mullet season of 1973. Bull Taiwan Fish Res Inst 24:55-94

Thomson JM (1966) The grey mullet. In: Barnes H (ed) Oceanography and marine biology-an annual review, Vol 4. Allen \& Unwin, London, p 301-355

Torricelli P, Tongiorgi P, Almansi P (1982) Migration of grey mullet fry into the Arno River: seasonal appearance, daily activity and feeding rhythms. Fish Res 1:219-234

Townsend DW, Radtke RL, Corwin S, Libby DA (1992) Strontium:calcium ratios in juvenile Atlantic herring (Clupea harengus L.) otoliths as a function of temperature. J Exp Mar Biol Ecol 160:131-140

Tsukamoto K, Arai T (2001) Facultative catadromy of the eel Anguilla japonica between freshwater and seawater habitats. Mar Ecol Prog Ser 220:265-276

Tung IH (1981) On the fishery biology of gray mullet, Mugil cephalus L., in Taiwan. Rep Inst Fish Biol Minist Econ Aff Natl Taiwan Univ 3:38-102

Tzeng WN (1994) Temperature effects on the incorporation of strontium in otolith of Japanese eel Anguilla japonica. J Fish Biol 45:1055-1066

Tzeng WN (1995) Migratory history recorded in otoliths of the Japanese eel, Anguilla japonica, elvers as revealed from SEM and WDS analyses. Zool Stud 34(Suppl 1):234-236

Tzeng WN (1996) Effects of salinity and ontogenetic movements on strontium:calcium ratios in the otoliths of the Japanese eel, Anguilla japonica Temminck and Schlegel. J Exp Mar Biol Ecol 199:111-122

Tzeng WN, Tsai YC (1994) Changes in otolith microchemistry of the Japanese eel, Anguilla japonica, during its migration from the ocean to the rivers of Taiwan. J Fish Biol 45: $671-683$

Tzeng WN, Severin KP, Wickström H (1997) Use of otolith microchemistry to investigate the environmental history of European eel Anguilla anguilla. Mar Ecol Prog Ser 149: $73-81$

Tzeng WN, Severin KP, Wickström H, Wang CH (1999) Strontium bands in relation to age marks in otoliths of European eel Anguilla anguilla. Zool Stud 38:452-457

Tzeng WN, Wang CH, Wickström H, Reizenstein M (2000) Occurrence of the semi-catadromous European eel Anguilla anguilla (L.) in Baltic Sea. Mar Biol 137:93-98

Tzeng WN, Shiao JC, Iizuka Y (2002a) Use of otolith Sr/Ca ratios to study the riverine migratory behaviors of Japanese eel Anguilla japonica. Mar Ecol Prog Ser 245:213-221

Tzeng WN, Wang YT, Chang CW (2002b) Spatial and temporal variations of the estuarine larval fish community on the west coast of Taiwan. Mar Freshw Res 53:419-430

Tzeng WN, Iizuka Y, Shiao JC, Yamada Y, Oka HP (2003) Identification and growth rates comparison of divergent migratory contingents of Japanese eel (Anguilla japonica). Aquaculture 216:77-86

Winer B (1971) Statistical principles in experimental design. McGraw-Hill, New York

Submitted: October 14, 2002; Accepted: November 21, 2003 Proofs received from author(s): March 15, 2004 